\title{
DIPTERAN ASSEMBLAGES IN RED-FOOTED FALCON (FALCO VESPERTINUS) NEST BOXES
}

\author{
Zoltán Soltész ${ }^{1,2}$, NÁndor Seres ${ }^{3}$ and Anikó KovÁcs-HostyÁnSZKi ${ }^{1}$ \\ ${ }^{1}$ Lendület Ecosystem Services Research Group, Centre for Ecological Research \\ Hungarian Academy of Sciences, H-2163 Vácrátót, Alkotmány u. 2-4, Hungary \\ E-mails: soltesz@entomologia.hu, kovacs.aniko@okologia.mta.hu \\ ${ }^{2}$ Department of Zoology, Hungarian Natural History Museum \\ H-1088 Budapest, Baross u. 13, Hungary \\ ${ }^{3}$ Bükk National Park Directorate H-3304 Eger, Sánc u. 6, Hungary \\ E-mail: seresnandi@gmail.com
}

The Red-footed Falcon (Falco vespertinus) is a strictly protected raptor species in Hungary (ca 600 pairs). It naturally breeds in rook, crow or magpie nests that are rebuilt every year, however, most of these nests disappeared by the end of the 20th century. In the early 2000's more than a 3,000 artificial nest boxes were installed in the country, increasing the number of breeding pairs considerably. This prompts the question whether breeding birds might face an increased number of nest-dwelling ectoparasites due to the annual re-use of nesting sites. The nest material was collected from 59 nest boxes (not cleaned for 3 years) in Northern Hungary after the breeding season in 2009 and from 17 nest boxes (cleaned in previous year) in 2010. Emerging dipteran imagoes were identified to species level. Altogether 45,487 individuals of 42 fly species (2010: 37, 2011: 14) were reared; $88.1 \%$ of that was Carnus hemapterus, a well-known blood-sucking parasite. The number of $C$. hemapterus was significantly higher in nests where the last breeding bird species was Common Kestrel than Red-footed Falcon. In freshly cleaned nest boxes one order of magnitude lower number of $C$. hemapterus specimens were found. Our results indicate the necessity of cleaning the nest boxes annually.

Key words: bird nest, Carnus hemapterus, nest box cleaning, parasites, saprophytic flies.

\section{INTRODUCTION}

In the 1940s about 2000-2500 pairs of Red-footed Falcons (Falco vespertinus Linnaeus, 1766) bred in Hungary predominantly using Rook (Corvus frugilegus Linnaeus, 1758) nests. However, due to poisoning of corvids and changes in land use including a decline of animal husbandry, approximately $90 \%$ of previously available rookeries either became demolished or moved to urban habitats (SERES \& Liker 2015) that are unsuitable for Red-footed Falcons (FEHÉRVÁRI et al. 2009). Consequently, by 2006 the estimated number of Red-footed Falcon pairs was reduced to less than 600. An international conservation 
program (LIFE05 NAT/H/000122) initiated in 2006 with the primary objective to halt this tendency succeeded in increasing the number of breeding pairs, primarily through provisioning over 3,500 nest boxes. Today, approximately two-thirds of Red-footed Falcon pairs breed in these man-made structures in Hungary (Palatitz et al. 2015). However, the breeding birds might face new challenges here as compared to their natural nesting sites.

Colonial species, such as the Red-footed Falcon may experience higher prevalence of ectoparasites than solitary breeders (Brown \& BRown 2004, RózSA et al. 1996) that constitutes one of the main costs of coloniality (BRown \& BRown 1986). Furthermore, while the Rook nests are rebuilt every year (HonVÁTH et al. 2015), food remains and faeces accumulate in the litter of artificial nest boxes through subsequent years. Consequently, the number of bloodsucking arthropods, such as certain dipteran flies developing, overwintering or breeding in the nest material may increase in the boxes from year to year, resulting in increased parasitism for the nesting birds (Møller et al. 1990). Furthermore, bird species other than Red-footed Falcon also use these artificial nest boxes and they can possibly increase the abundance and diversity of ectoparasitic insects living there.

The nest-dwelling dipteran larvae are either (i) parasites sucking the birds' blood or tissue fluids, (ii) or enter the nestlings' epidermis to cause myiasis, (iii) or saprophages feeding on the litter and other organic substrates, (iv) or predators of other nidicolous invertebrates. Imagoes of some dipterans are sucking avian blood, while adults of some other fly species use avian nests as overwintering shelters.

Blood-sucking and nest-dwelling dipteran flies can exert various effects on avian broods. They might decrease the chicks' condition (Hor et al. 2010), increase nestling mortality (RICHNER et al. 1993), increase physiological stress (Martínez-Padilla et al. 2004, Tomás et al. 2008, Cantarero et al. 2013), or decrease their fitness indirectly by transmission of blood parasites (RICHNER et al. 1993, Martínez-De La Puente et al. 2013).

In this study we investigated the dipteran assemblages of 3 years old accumulated, and one year old fresh nest materials from nest boxes after the breeding season of Red-footed Falcons. We aimed to answer the following questions:

1) was the species richness and abundance of the dipteran larval assemblages in the 3-year-old nesting material affected by the (i) number of breeding bird species during the former 3 years; (ii) or the species of the last bird breeding in the box?

2) What is the composition of the Diptera community in the 3 years versus the 1 year old accumulated nest material?

3) Is the hatching of Carnus hemapterus synchronised with the breeding periods of the different bird species using the same box? 


\section{MATERIAL AND METHODS}

\section{Study site and sampling}

Field work was carried out in Borsodi-Mezőség, Mezőcsát (N47,769 E20,892 ${ }^{\circ}$, Mezőnagymihály $\left(\mathrm{N} 47,788^{\circ} \mathrm{E} 20,818^{\circ}\right)$, at the protected area of the Bükk National Park Directorate in Northern Hungary in 2009 and 2010. Over 60-80 pairs of Red-footed Falcons bred in this area in nearly 200 artificial nest boxes each year, along with numerous Common Kestrels (Falco tinnunculus Linnaeus, 1758), Jackdaws (Corvus monedula Linnaeus, 1758) and Long-eared Owls (Asio otus (Linnaeus, 1758)). The investigated nest boxes were installed in the crown of Black locust (Robinia pseudoacacia) and poplar (Populus sp.) trees in 2006. The usual breeding bird sequence in a year is the following: Jackdaw, Long-eared Owl, Kestrel, Red-footed Falcon. Generally, Red-footed Falcons and the Kestrels start the breeding when the fledgling of Jackdaws left the nest boxes and, therefore, two consecutive species may occupy a given nest box in the same breeding season.

In 2009 we collected nest material

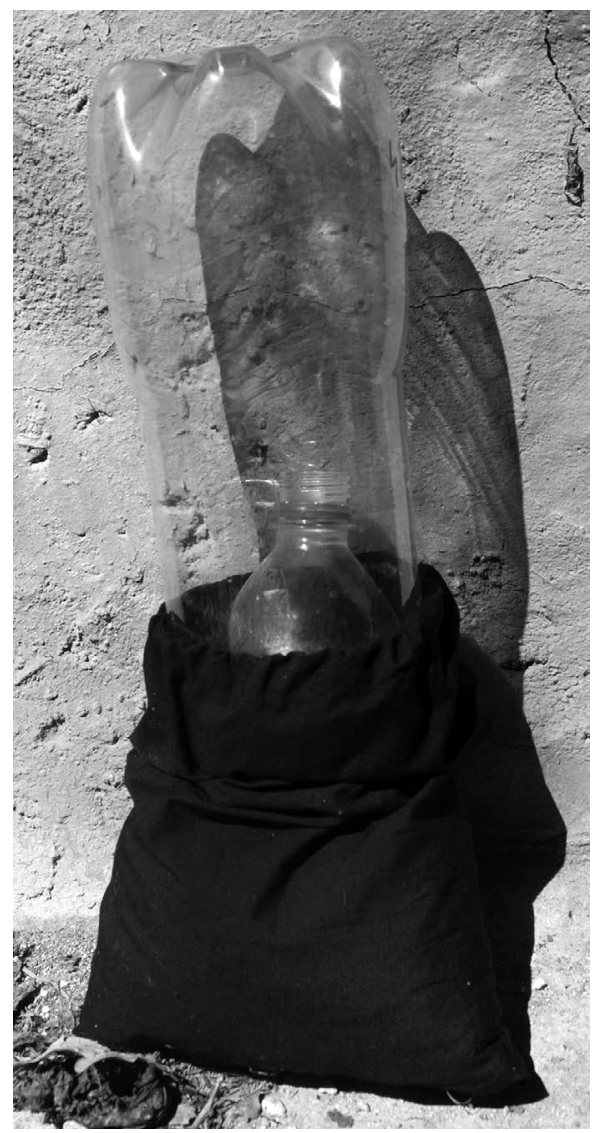

Fig.1. Linen sack with translucent PET bottles were used to trap the hatching flies from 59 nest boxes that were not cleaned for 3 years, while in 2010 we sampled the oneyear old nest material from 17 nest boxes, cleaned in the year before. In the 2009 breeding season, the bird species breeding in the nest boxes were Long-eared Owl $(n=5)$, Jackdaw followed by Red-footed Falcon or Common Kestrel $(\mathrm{n}=6)$, Red-footed Falcon $(\mathrm{n}=16)$, Common Kestrel $(\mathrm{n}=32)$; in 2010 all the nest boxes were occupied by Red-footed Falcon $(n=17)$. The nest materials were collected both years in October, when the nestlings already flew out, and stored in $10 \times 30$ $\mathrm{cm}$ linen sacks. As the identification of dipteran larvae is generally very difficult even at family level (Sмiтн et al. 2000), we decided to rear the larvae to adults. We overwintered the nest substance in a cellar (to ensure stable temperature and similar overwintering probability). Translucent PET bottles were used in order to trap the hatching flies (Fig. 1). The hatching insects were collected in the next year from the end of April till August in every two weeks. All reared specimens were identified to species level.

\section{Statistical analyses}

We used generalized linear mixed effects models (GLMMs) to assess effects of number of breeding species over the 3 years, and the last breeding species on the species 
richness and abundance of all dipteran species and the abundance of Carnus hemapterus. Abundance of all dipterans and that of $C$. hemapterus were $\log 10$ transformed to reach normal residual distribution. We tested all predictor variables for multicollinearity by calculating the variance inflation factor (VIF) using vif function or Chi-squared test of independence for categorial variables. A maximum VIF value of 5 was taken as an indicator of multicollinearity (Rogerson 2001). The abundance of all dipterans was analysed at nest box level as collected, which were nested according to the colonies and those in settlements as random factors: settlement/colony. In addition, all pair-wise interactions were tested between the explanatory variables. Terms were removed sequentially in backward stepwise selection until only significant interactions and main effects $(P>0.05$ from $F$ test) remained in the minimal adequate model. All analyses were carried out in $R$, version 3.2.3 (R Core Team 2016) using the following packages: nlme (Pinheiro et al. 2017), stats (R Core Team 2016) and fmsb (NAKAZAwa 2015).

\section{RESULTS}

During the two-year study period 45,487 specimens of 42 dipteran species (2010: 37 species; 2011: 14 species) were reared from the 76 nests. According to the feeding habit of the larvae, 10 species (Muscidae, Sarcophagidae and Scenopinidae) were predatory, 32 species saprophagous, and only imagoes of 2 species proved to be blood-suckers. The overwhelming majority $(88.1 \%)$ of individuals represented a single species, Carnus hemapterus (Table 1).

Table 1. Dipteran species reared, their larval feeding habit (LFH), total number of individuals (N) and occurrence ratio (OR) in the three-years old (2009) and one-year old (2010) nest box material. Abbreviation: $S A=$ saprophagous, $P R=$ predator.

\begin{tabular}{|c|c|c|c|c|c|c|}
\hline \multirow[b]{2}{*}{ Family } & \multirow[b]{2}{*}{ Species } & \multirow[b]{2}{*}{ LFH } & \multicolumn{2}{|c|}{2009} & \multicolumn{2}{|c|}{2010} \\
\hline & & & $\mathrm{N}$ & $\begin{array}{l}\text { OR } \\
(\%)\end{array}$ & $\mathrm{N}$ & $\begin{array}{l}\text { OR } \\
(\%)\end{array}$ \\
\hline $\begin{array}{l}\text { Antho- } \\
\text { myiidae }\end{array}$ & Anthomyia procellaris Rondani, 1866 & SA & 10 & 10.2 & 21 & 29.4 \\
\hline \multirow{5}{*}{ Carnidae } & Carnus hemapterus Nitzsch, 1818 & SA & 39795 & 96.6 & 283 & 76.5 \\
\hline & Hemeromyia anthracina Collin, 1949 & SA & 586 & 64.4 & 14 & 17.6 \\
\hline & Hemeromyia longirostris Carles-Tolra, 1992 & SA & 8 & 8.5 & 0 & 0 \\
\hline & Meoneura neottiophila Collin, 1930 & SA & 0 & 0 & 8 & 23.5 \\
\hline & Meoneura prima (Becker, 1903) & SA & 43 & 18.6 & 0 & 0 \\
\hline \multicolumn{2}{|c|}{ Cecidomyidae } & SA & 134 & 18.6 & 0 & 0 \\
\hline \multirow{3}{*}{$\begin{array}{l}\text { Droso- } \\
\text { philidae }\end{array}$} & Drosophila bifasciata Pomini, 1940 & SA & 1 & 1.7 & 0 & 0 \\
\hline & Drosophila busckii Coquillett, 1901 & SA & 2 & 1.7 & 0 & 0 \\
\hline & Fannia canicularis (Linnaeus, 1761) & SA & 24 & 20.3 & 0 & 0 \\
\hline \multirow[t]{2}{*}{ Fanniidae } & Fannia lineata (Stein, 1895) & SA & 3 & 1.7 & 0 & 0 \\
\hline & Fannia manicata (Meigen, 1826) & SA & 2 & 1.7 & 0 & 0 \\
\hline
\end{tabular}




\begin{tabular}{|c|c|c|c|c|c|c|}
\hline \multirow[b]{2}{*}{ Family } & \multirow[b]{2}{*}{ Species } & \multirow[b]{2}{*}{ LFH } & \multicolumn{2}{|c|}{2009} & \multicolumn{2}{|c|}{2010} \\
\hline & & & $\mathrm{N}$ & $\begin{array}{l}\text { OR } \\
(\%) \\
\end{array}$ & $\mathrm{N}$ & $\begin{array}{l}\text { OR } \\
(\%) \\
\end{array}$ \\
\hline \multirow{3}{*}{ Fanniidae } & Fannia scalaris (Fabricius, 1794) & SA & 2 & 1.7 & 0 & 0 \\
\hline & Fannia sp. 1 & SA & 1 & 1.7 & 0 & 0 \\
\hline & Fannia sp. 2 & SA & 1 & 1.7 & 0 & 0 \\
\hline \multirow{4}{*}{$\begin{array}{l}\text { Heleomy- } \\
\text { zidae }\end{array}$} & Chiropteromyza broersei (de Meijere, 1946) & SA & 12 & 3.4 & 25 & 5.9 \\
\hline & Tephrochlamys laeta (Meigen, 1830) & SA & 1 & 1.7 & 0 & 0 \\
\hline & Tephrochlamys rufiventris (Meigen, 1830) & SA & 21 & 20.3 & 0 & 0 \\
\hline & Tephrochlamys tarsalis (Zetterstedt, 1847) & SA & 1338 & 50.8 & 1378 & 94.1 \\
\hline $\begin{array}{l}\text { Hippo- } \\
\text { boscidae }\end{array}$ & Ornithoica turdi (Olivier in Latreille, 1811) & SA & 1 & 1.7 & 0 & 0 \\
\hline \multirow{2}{*}{$\begin{array}{l}\text { Milichii- } \\
\text { dae }\end{array}$} & Leptometopa latipes (Meigen, 1830) & SA & 1451 & 71.2 & 118 & 82.4 \\
\hline & Madiza glabra Fallén, 1820 & SA & 11 & 3.4 & 0 & 0 \\
\hline \multirow{7}{*}{ Muscidae } & Hydrotaea armipes (Fallén, 1825) & PR & 13 & 6.8 & 0 & 0 \\
\hline & Hydrotaea hennigi Pont, 1985 & PR & 0 & 0 & 1 & 5.9 \\
\hline & Hydrotaea sp. & PR & 0 & 0 & 1 & 5.9 \\
\hline & Muscidae sp. 1 & PR & 1 & 1.7 & 0 & 0 \\
\hline & Muscidae sp. 2 & PR & 8 & 1.7 & 0 & 0 \\
\hline & Muscina stabulans (Fallén, 1817) & PR & 0 & 0 & 8 & 23.5 \\
\hline & Potamia littoralis Robineau-Desvoidy, 1830 & PR & 5 & 5.1 & 0 & 0 \\
\hline $\begin{array}{l}\text { Psycho- } \\
\text { didae }\end{array}$ & Psychoda minuta Banks, 1894 & SA & 0 & 0 & 59 & 35.3 \\
\hline \multirow{2}{*}{$\begin{array}{l}\text { Sarco- } \\
\text { phagidae }\end{array}$} & $\begin{array}{l}\text { Sarcophaga argyrostoma (Robineau-Des- } \\
\text { voidy, 1830) }\end{array}$ & PR & 11 & 5.1 & 0 & 0 \\
\hline & Sarcophagidae sp. & PR & 1 & 1.7 & 0 & 0 \\
\hline $\begin{array}{l}\text { Scenopi- } \\
\text { nidae }\end{array}$ & Scenopinus fenestralis (Linnaeus, 1758) & PR & 30 & 27.1 & 0 & 0 \\
\hline \multirow{2}{*}{ Sciaridae } & Bradysia sp. & SA & 1 & 1.7 & 0 & 0 \\
\hline & Sciaridae sp. & SA & 1 & 1.7 & 0 & 0 \\
\hline \multirow{8}{*}{$\begin{array}{l}\text { Sphaero- } \\
\text { ceridae }\end{array}$} & Apteromyia claviventris (Strobl, 1909) & SA & 0 & 0 & 4 & 17.6 \\
\hline & Coproica hirtula (Rondani, 1880) & SA & 11 & 10.2 & 0 & 0 \\
\hline & Ischiolepta pusilla (Fallén, 1820) & SA & 4 & 6.8 & 0 & 0 \\
\hline & Spelobia sp. & SA & 1 & 1.7 & 0 & 0 \\
\hline & Spelobia luteilabris (Rondani, 1880) & SA & 0 & 0 & 11 & 17.6 \\
\hline & Spelobia pseudosetaria (Duda, 1918) & SA & 15 & 15.3 & 6 & 17.6 \\
\hline & Telomerina flavipes (Meigen, 1830) & SA & 1 & 1.7 & 0 & 0 \\
\hline & Total & & 43550 & & 1937 & \\
\hline
\end{tabular}


In boxes with nest material accumulated through three years, only the species identity of the last breeding bird had a significant effect on the number of $C$. hemapterus ( $\mathrm{df}=52, \mathrm{~F}=4.187, p=0.046)$. It was significantly higher when Common Kestrels bred in the same box in the former year, as compared to Red-footed Falcons $(t=2.1, \mathrm{df}=48.572, p=0.041)$.

The average number of $C$. hemapterus in 2009 (3-year old nest material) was $674.5 \mathrm{ind} . /$ nest, while in 2010 (one year old nest material) it was 16.6 ind./ nest. The hatching time curve of $C$. hemapterus was bimodal from the 2009 nest material from those nests, where both Jackdaws (early peak in May) and Kestrels or Red-Footed Falcons (a second peak in July) bred. Contrarily, this curve was unimodal from nest boxes with only one late breeding bird species in the last year, with its maximum in the second part of the summer (Fig. 2).

\section{DISCUSSION}

The breeding population of the Red-footed Falcon has been successfully increased in Hungary by using artificial nest boxes during the last ten years

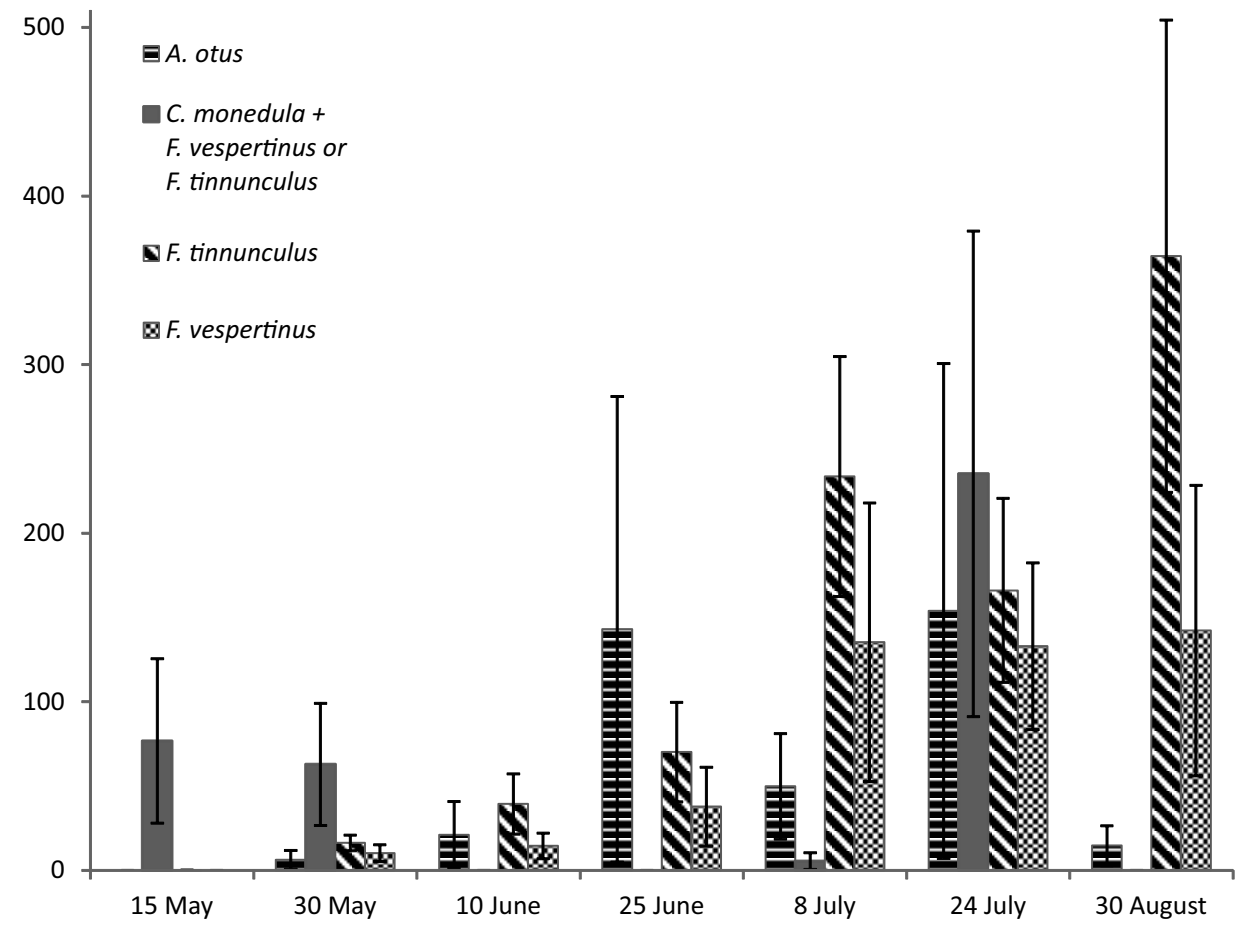

Fig. 2. Phenology of emergence of Carnus hemapterus imagoes from three years old accumulated nest material (collected in 2009), grouped by the last breeding bird species ( $\mathrm{n}=$ number of nest boxes) within the nest (mean \pm SEM) 
(Palatitz et al. 2015). The adjoining arthropod communities in the accumulating nest material and the potential harms they may cause to the nestlings, however, are still poorly known. There are only a few studies dealing with the dipteran communities of the nests of raptor birds (Philips \& Dindal 1990, KaLAvský et al. 2009). In our study we sampled the Diptera assemblages of these artificial nest boxes and our aim was to survey the entire dipteran fauna connected to the nest boxes with a special focus on parasitic flies.

Our investigations have been carried out in two separate nest box colonies installed for Red-footed Falcons. During the two years of sampling from 76 nest box materials, in which four bird species bred, altogether 45,487 dipteran specimens belonging to 42 species were reared. These numbers, regarding both the number of species and individuals, are remarkably higher than found in raptor bird nests by the former investigations (Philips \& Dindal 1990, Papp \& Paulovics 2002, Kal'avský et al. 2009, Lesko \& Smallwood 2012, LANGE 2015). A possible reason for this difference is the different breeding habit of the birds, as most raptors are solitary breeders, while the Red-footed Falcon tends to breed colonially. Colonial species may experience higher prevalence of ectoparasites as compared to solitary breeders (Rózsa et al. 1996, BRown \& BROWN 2004).

Analysing the frequency of the dipteran species in our samples, we found that $90 \%$ of the species ( 38 species) were rare (i.e., less than $0.01 \%$ of the whole sample). This ratio is very similar to that of found in case of free-living dipteran species utilizing point-like food sources, such as dung, fermenting fruit etc. (PAPp 1998). The majority of the reared individuals were C. hemapterus, a well-known blood-sucking parasite of bird chicks. Due to ethical reasons, we collected nest materials only after all birds left the colony, and probably this is the reason why we found no parasitic Calliphoridae and Muscidae specimens.

In former investigations, only 8 dipteran species, C. hemapterus, Cynomya mortuorum, Meoneura neottiophila, Ornithomya avicularia, Potamia littoralis, Protocalliphora avium, Scenopinus fenestralis and Scoliocentra brachypterna were known to occur in the nests of the four bird species involved in our study (Red-footed Falcon, Common Kestrel, Jackdaw and Long-eared Owl) (Hicks 1959, Нicks 1962, Bohm 1978, Rotheray 2012, Аmat-Valero et al. 2013, SumasGUTNER et al. 2014, LANGE 2015). We found only three of these species (C. hemapterus, M. neottiophila, S. fenestralis), therefore, all the other 39 species are new for the nest fauna of these birds. It is worth mentioning that while the samples collected in 2009 originated from the nests used by four bird species, the samples from 2010 were exclusively from the nest boxes of the Red-footed Falcon. Formerly only C. hemapterus was found in the nests of Red-footed Falcon (Нicks 1962, FeHÉrvári et al. 2015) and, therefore, the additional 13 dipteran species recorded from the 2010 samples are reported here for the first time to occur in the nests of $F$. vespertinus. The samples included 8 dipteran species 
(Drosophila bifasciata, Drosophila busckii, Hydrotaea hennigi, Psychoda minuta, Coproica hirtula, Spelobia pseudosetaria) which were recorded by us for the first time to occur in avian nests. In addition, one of the species, Fannia lineata, is new for the fauna of Hungary. Since formerly only a very few studies targeted the dipteran assemblages of the bird nests in Hungary (LiKER et al. 2001, PAPP \& Paulovics 2002), the occurrence of this Fannia species in the Hungarian fauna was probably overlooked.

Carnus hemapterus is an obligatory nest-dwelling avian ectoparasite, having been found in the nests of $>50$ bird species (Grimaldi 1997, BraKe 2011) including raptors. Certain studies indicated that $C$. hemapterus infestations had a negative effect on the condition of the chicks of Colaptes auratus (WIEBE 2009), Sturnus unicolor (Avilés et al. 2009) and Merops apiaster (Hoi et al. 2010), but no significant negative effects were found in case of raptors (DAwson \& Bortolotti 1997, Kalavský et al. 2010). However, apart from blood loss and discomfort caused by their bites, these flies are also important as vectors of Plasmodium and Haemoproteus infections (Vaclav et al. 2016).

In the nest litter accumulated through three consecutive years, the number of Carnus hemapterus individuals was on average an order of magnitude higher than in the one year old nest materials. The formerly published data on the abundance of $C$. hemapterus (Liker et al. 2001, VALERA et al. 2003, SumasGUTNER et al. 2014) were roughly similar to our samples from the one-year old nest boxes. This fact indicates a marked increase of $C$. hemapterus abundance during the re-use of nest through consecutive years. Certain investigations pointed out that in the nests of Kestrels (Sumasgutner et al. 2014) and Barn Owls (Roulin 1998) the abundance of $C$. hemapterus was higher in nests with accumulated litter than in cleaned ones. Although in these cases there was no significant correlation between the increased parasite numbers and the breeding success, the accumulation periods were shorter and the increase of parasite abundance was much smaller than in our study. In nests not cleaned for years, the increase of $C$. hemapterus abundance is supposedly greater because the pupae may exhibit diapause through several years (VALERA et al. 2006). Furthermore, the saprophagous larvae may also benefit form greater food resources and higher relative humidity in the accumulating debris of uncleaned nest boxes. The lower competition of larvae for the larger amount of multi-years nest material could also positively influence the development and survival of immatures and, consequently, the number of hatched adults. The nest boxes in the Hungarian breeding colonies are often not cleaned every year, therefore, subsequent studies should clarify the effect of accumulated nest litter on the breeding conditions of birds.

Our study indicated that the abundance of $C$. hemapterus was significantly higher when the Kestrel was the last breeder in the nest box, as compared 
to cases when the Red-footed Falcon was the ultimate breeder. The reason of this difference could be the different size of their broods: the Kestrel is larger-bodied and it has usually 5-6 nestlings, while the Red-footed Falcon is smaller and it has only 3-4 chicks. Supposedly, a larger mass of chicks in Kestrel broods may maintain more parasitic flies, that can lay more eggs and, therefore, the abundance of the next generation of flies may be larger as well.

The synchronisation of the $C$. hemapterus generations to bird breeding was recorded in different nestling developmental stages of the same bird species (Liker et al. 2001, Calero-Torralbo et al. 2013), as well as to different bird species breeding in the same area, but not in the same nests (VALERA et al. 2003). This synchronisation is inevitable for the flies because the freshly hatched adults die without feeding within 2-3 days (CALero-Torralbo et al. 2013). We also observed synchronisation to 2 bird species subsequently occupying the same nest within a single breeding season. In the samples hatching in 2010 there were two peaks of $C$. hemapterus abundance (in May and in July) in the nest boxes used by Jackdaws and Falco spp., while there was only one summer peak in the other nests used only by Falco spp. (Fig. 2). This likely indicates that some of the flies synchronised their life cycle to Jackdaws, while others to the Common Kestrels and Red-footed Falcons that breed remarkably later.

Our study demonstrates that the nest boxes installed for the Red-footed Falcons and used by more bird species are inhabited by surprisingly diverse dipteran assemblages. We plan future studies to investigate the behaviour of parasitic dipterans and to compare the composition of fly assemblages in colonial versus solitary nest boxes. Moreover, the comparison of the assemblages of these nest boxes and the natural breeding sites in Rook colonies would provide further important information about the accommodation of these dipteran groups to the different nest types. Finally, further studies would be necessary to clarify the possible effect of the accumulation of nest litter to the composition and abundance of the dipteran assemblages inhabiting avian nests.

Acknowledgements - We would like to thank László Papp for his help in planning the study and identification of flies, and László Peregovits, László Ronkay and Péter Fehérvári for their comments on an earlier version of the manuscript. We would like to also thank for the "Conservation of Falco vespertinus in the Pannonian Region" Life program (LIFE05 NAT/H/000122) for installing the nest boxes. We are grateful to András Kleszó and Tamás Szitta (Bükk local group of MME/BirdLife Hungary) for their help in the collection of nest materials. 


\section{REFERENCES}

Amat-Valero, M., Calero-Torralbo, M. A. \& Valera, F. (2013): Temperature during the free-living phase of an ectoparasite influences the emergence pattern of the infective phase. - Parasitology 140: 1357-1367. https://doi.org/10.1017/S0031182013000929

Avilés, J. M., Pérez-Contreras, T., Navarro, C. \& Soler, J. J. (2009): Male spotless starlings adjust feeding effort based on egg spots revealing ectoparasite load. - Animal Behaviour 78: 993-999. https://doi.org/10.1016/j.anbehav.2009.07.020

Вонм, R. T. (1978): Protocalliphora infestation in great horned owls. - Wilson Bulletin 90: 297.

BRAKE, I. (2011): World catalog of the family Carnidae (Diptera, Schizophora). - Contributions to the Systema Dipterorum (Insecta: Diptera). Myia 12: 113-169.

Brown, C. R. \& Brown, M. B. (1986): Ectoparasitism as a cost of coloniality in cliff swallows (Hirundo pyrrhonota). - Ecology 67: 1206-1218. https://doi.org/10.2307/1938676

Brown, C. R. \& Brown, M. B. (2004): Empirical measurement of parasite transmission between groups in a colonial bird. - Ecology 85: 1619-1626. https://doi.org/10.1890/03-0206

Calero-Torralbo, M. A., Vaclav, R. \& Valera, F. (2013): Intra-specific variability in lifecycle synchronization of an ectoparasitic fly to its avian host. - Oikos 122: 274-284. https://doi.org/10.1111/j.1600-0706.2012.20374.x

Cantarero, A., López-Arrabé, J., Rodríguez-García, V., González-Braojos, S., Ruiz-DeCastañeda, R., Redondo, A. J. \& Moreno, J. (2013): Factors affecting the presence and abundance of generalist ectoparasites in nests of three sympatric hole-nesting bird species. - Acta Ornithologica 48: 39-54. https://doi.org/10.3161/000164513X669982

Dawson, R. D. \& BовтоцоттI, G. R. (1997): Ecology of parasitism of nestling American kestrels by Carnus hemapterus (Diptera: Carnidae). - Canadian Journal of Zoology 75: 2021-2026. https://doi.org/10.1139/z97-835

Fehérvári, P., Harnos, A., Neidert, D., Solt, S. \& Palatitz, P. (2009): Modeling habitat selection of the red-footed falcon (Falco vespertinus): a possible explanation of recent changes in breeding range within Hungary. - Applied Ecology and Environment 7: 59-69.

Fehérvári, P., Piross, I. S., Kotymán, L., Solt, S., Horváth, É. \& Palatitz, P. (2015): Species specific effect of nest-box cleaning on settlement selection decisions in an artificial colony system. - Ornis Hungarica 23: 66-76. https://doi.org/10.1515/orhu-2015-0006

Grimaldi, D. (1997): The bird flies, genus Carnus: species revision, generic relationships, and a fossil Meoneura in amber (Diptera: Carnidae). - American Museum Novitates 3190: $1-30$.

Hicкs, E. A. (1959): Check-list and bibliography on the occurrence of insects in birds' nests. - Iowa State University Press, Ames, 681 pp.

Нiскs, E. A. (1962): Check-list and bibliography on the occurrence of insects in birds' nests: Supplement 1. - Iowa State Journal of Science 36(3): 233-348.

Hoi, H., KristofiK, J., Darolova, A. \& Hoi, C. (2010): Are parasite intensity and related costs of the milichiid fly Carnus hemapterus related to host sociality? - Journal of Ornithology 151: 907-913. https://doi.org/10.1007/s00265-014-1808-6

Horváth, É., Solt, S., Kotymán, L., Palatitz, P., Piross, I. S. \& Fehérvári, P. (2015): Provisioning nest material for Rooks; a potential tool for conservation management. Ornis Hungarica 23: 22-31. https://doi.org/10.1515/orhu-2015-0002

KalavskÝ, M., FenĎA, P. \& Holecová, M. (2009): Arthropods in the nests of the Common Kestrel (Falco tinnunculus). - Slovak Raptor Journal 3: 29-33. 
Kalavský, M. \& Pospisilova, B. (2010): The ecology of ectoparasitic species Carnus hemapterus on nestlings of common kestrel (Falco tinnunculus) in Bratislava. - Slovak Raptor Journal 4: 45-48.

LANGE, L. (2015): The carnid fly Carnus hemapterus in the Steinburg district (Itzehoe, Schleswig-Holstein) also found on the eagle owl. - EulenWelt 2015: 38-39.

LesKo, M. J. \& SMAllwood, J. A. (2012): Ectoparasites of American Kestrels in northwestern New Jersey and their relationship to nestling growth and survival. - Journal of Raptor Research 46: 304-313. https://doi.org/10.3356/JRR-11-56.1

Liker, A., Markus, M., Vozar, A., Zemankovics, E. \& Rozsa, L. (2001): Distribution of Carnus hemapterus in a starling colony. - Canadian Journal of Zoology 79: 574-580. https:// doi.org/10.1139/cjz-79-4-574

Martínez-De la Puente, J., Martínez, J., Rivero-De-Aguilar, J., Del Cerro, S. \& Merino, S. (2013): Vector abundance determines Trypanosoma prevalence in nestling blue tits. - Parasitology 140: 1009-1015. https://doi.org/10.1017/S0031182013000371

Martínez-Padilla, J., Martínez, J., Dávila, J., Merino, S., Moreno, J. \& Millán, J. (2004): Within-brood size differences, sex and parasites determine blood stress protein levels in Eurasian kestrel nestlings. - Functional Ecology 18: 426-434. https://doi.org/10.1111/ j.0269-8463.2004.00874.x

Møller, A. P., Allander, K. \& Dufva, R. (1990): Fitness effects of parasites on passerine birds: a review. Pp. 269-280. - In: Population biology of passerine birds. Springer.

Nakazawa, M. (2015): fmsb: Functions for Medical Statistics Book with some Demographic Data. R package version 0.5.2. https:/CRAN.R-project.org/package $=$ fmsb

Palatitz, P., Fehérvári, P., Solt, S. \& Horváth, É. (2015): Breeding population trends and pre-migration roost site survey of the Red-footed Falcon in Hungary. - Ornis Hungarica 23: 77-93.

PApp, L. (1998): “Outlaws": some evolutionary aspects of rarity in insects. - Tiscia 31: 29-33.

Papp, L. \& Paulovics, P. (2002): On the life-habits and developmental stages of Nidomyia cana Papp (Diptera, Borboropsidae). - Journal of Natural History 36: 979-989. https:// doi.org/10.1080/00222930110061850

Philips, J. \& Dindal, D. (1990): Invertebrate populations in the nests of a screech owl (Otus asio) and an American kestrel (Falco sparverius) in central New York. - Entomological News 101: 170-192.

Pinheiro, J., Bates, D., DebRoy, S., Sarkar, D. \& Team, R. C. (2017): nlme: Linear and Nonlinear Mixed Effects Models. R package version 3.1-131. 2017. http://CRAN.R-project.org/package $=$ nlme

R Core TeAm (2016): A Language and Environment for Statistical Computing. - R Foundation for Statistical Computing, Vienna, Austria 2016. http://www.R-project.org

Richner, H., Oppliger, A. \& Christe, P. (1993): Effect of an ectoparasite on reproduction in great tits. - Journal of Animal Ecology 62(4): 703-710.

Rogerson, P. (2001): Statistical methods for geography. - Sage. London, 236 pp.

Rotheray, G. E. (2012): Morphology of the puparium and breeding sites of eight species of Heleomyzidae (Diptera). - Journal of Natural History 46: 2075-2102.

Roulin, A. (1998): Reproductive cycle and abundance of Carnus hemapterus a parasitic diptereae in barn own Tyto alba broods. - Alauda 66: 265-272.

RózsA, L., RéKÁsi, J. \& REICZIGEL, J. (1996): Relationship of host coloniality to the population ecology of avian lice (Insecta: Phthiraptera). - Journal of Animal Ecology 65(2): 242-248.

Seres, G. \& Liker, A. (2015): Habitat urbanization and its effects on birds. - Acta Zoologica Academiae Scientiarum Hungaricae 61(4): 373-408. https://doi.org/10.17109/ AZH.61.4.373.2015 
Smith, K. G. V. \& Ferrar, P. (2000): 1.6. Key to families - larvae. Pp. 2001-2239. In: Papp, L. \& Darvas, B. (eds): Contributions to a manual of Palaearctic Diptera, vol. 1. - Science Herald, Budapest.

Sumasgutner, P., Vasko, V., Varjonen, R. \& Korpimaki, E. (2014): Public information revealed by pellets in nest sites is more important than ecto-parasite avoidance in the settlement decisions of Eurasian kestrels. - Behavioral Ecology and Sociobiology 68: 2023-2034. https://doi.org/10.1007/s00265-014-1808-6

Tomás, G., Merino, S., Martínez-de la Puente, J., Moreno, J., Morales, J. \& Lobato, E. (2008): Determinants of abundance and effects of blood-sucking flying insects in the nest of a hole-nesting bird. - Oecologia 156: 305-312. https://doi.org/10.1007/s00442008-1001-6

Václav, R., Bétaková, T., Švančarová, P., Pérez-Serrano, J., Criado-Fornelio, Á., ŠKorVANOvÁ, L. \& VAlERA, F. (2016): Nest ecology of blood parasites in the European roller and its ectoparasitic carnid fly. - Experimental Parasitology 165: 71-80. https:// doi.org/10.1016/j.exppara.2016.03.014

Valera, F., Casas-Criville, A. \& Calero-Torralbo, M. A. (2006): Prolonged diapause in the ectoparasite Carnus hemapterus (Diptera: Cyclorrhapha, Acalyptratae) how frequent is it in parasites. - Parasitology 133: 179-186. https://doi.org/10.1017/ s0031182006009899

Valera, F., Casas-Criville, A. \& Hoi, H. (2003): Interspecific parasite exchange in a mixed colony of birds. - Journal of Parasitology 89: 245-250. https://doi.org/10.1645/00223395(2003)089[0245:ipeiam]2.0.co;2

Wiebe, K. L. (2009): Nest excavation does not reduce harmful effects of ectoparasitism: an experiment with a woodpecker, the northern flicker Colaptes auratus. - Journal of Avian Biology 40: 166-172. https://doi.org/10.1111/j.1600-048X.2009.04481.x

Received April 12, 2017, accepted July 19, 2017, published March 30, 2018 